\title{
Isolation and characterisation of Vibrio harveyi as etiological agent of foot pustule disease in the abalone Haliotis discus hannai Ino 1953
}

\author{
R. X. WANG, T. YAO, X. J. LIU AND J. Y. WANG* \\ South China Sea Fisheries Research Institute, Chinese Academy of Fishery Sciences, Guangzhou - 510 300, China \\ ${ }^{*}$ Key Laboratory of South China Sea Fishery Resources Exploitation and Utilisation, Ministry of Agriculture, P. R. China \\ e-mail:wrxlxwlld@163.com
}

\begin{abstract}
Foot pustule disease is an important disease affecting abalones. In the present study, microbiological and histopathological investigations were carried out in the Japanese abalone Haliotis discus hannai, affected by foot pustule disease. Diseased abalones became lethargic, weak and eventually died. The remarkable symptoms were apparent foot pustules and atrophy of the foot muscle. A predominant bacterium designated as BV2 was isolated from the pustules of diseased abalones. Experimental infection by immersion challenge showed that BV2 was virulent to abalones and caused symptoms of foot pustule disease with median lethal dose value of $\approx 7.76 \times 10^{5} \mathrm{cfu} \mathrm{ml}^{-1}$. BV2 was infectious to all tested abalones with high mortality. Histopathological investigations showed degeneration and collapse of foot muscles as well as connective tissues. Tissues in round pustules were necrotic and disorganised. The BV2 bacterium was identified as Vibrio harveyi based on the results of phenotypic and biochemical tests as well as $16 \mathrm{~S}$ rRNA gene sequence analysis.. The bacterium was found resistant to kanamycin and clindamycin, and sensitive to other 11 antibiotics tested.
\end{abstract}

Keywords: Abalone, Antibiotics, Foot pustule, Haliotis discus hannai Pathogen, Vibrio harveyi

\section{Introduction}

Abalones are marine gastropods that can be found worldwide in temperate and tropical waters from intertidal zones to a depth of $40 \mathrm{~m}$. Abalone aquaculture began in the 1960s in the United States and Japan (McBride, 1998) and has since become a well-established industry in China, Korea, Australia, Chile, USA, Mexico and New Zealand (Flores-Aguilar et al., 2007; Allsopp et al., 2012). More than $90 \%$ of the world abalone production is based on farming (Jo et al., 2014). China is one of the world's primary abalone-producing countries, with production of 110380 t during 2013 (Chinese fishery statistical yearbook, 2014). Haliotis discus hannai Ino 1953 and their hybrids are the predominant abalone species cultured onshore in coastal areas of China. Abalone aquaculture is an intensive industry, which is often land-based, with tanks stocked at high density. Given the crowding and suboptimal environmental conditions compared with conditions in the wild (Shepherd, 1973; Goodsell et al., 2006; Gorski and Nugegoda, 2006), abalones in aquaculture systems are vulnerable to infection by microorganisms that are often ubiquitous (Jo et al., 2014).

Chinese abalone farmers face significant challenges as the financial commitments are high to bring temperate abalones to market size which can take up to 3 years. Deteriorating environmental conditions and infectious diseases have also become major challenges that have long threatened the abalone aquaculture industry, especially during summer (Wang et al., 2008). Outbreaks of infectious diseases leading to mass mortality events of cultured abalones, result in catastrophic losses to aquaculturists. Vibrio has been described as a predominant pathogenic bacterium of cultured abalones (Gauger and Gomez-Chiarri, 2002; Wang et al., 2006; Travers et al., 2010; Wang et al., 2010; Schikorski et al., 2013). Vibriosis is the most common disease caused by pathogenic bacteria in halophilic environments and this disease affects several groups of organisms (Cardinaud et al., 2015; Ananda Raja et al., 2017a, b). Mortality in physiologically depressed abalone, $H$. tuberculata, in seawater at temperatures higher than $16^{\circ} \mathrm{C}$ has been attributed to the bacterial pathogen Vibrio harveyi (Travers et al., 2009; Cardinaud et al., 2014). Abalone foot pustule disease is a serious and chronic disease caused by Vibrio spp. infection in both natural and farmed populations; which was recorded for the first time in 1993 (Li et al., 1997; Huang, 2005). Almost all infected abalones display obvious white pustules and present signs of atrophy in the feet as well as a malformed appearance. The epidemic nature of this disease leads to high rate of mortality. Furthermore, this disease has been associated with serious economic losses (Chen et al., 2011). 
The current study reports the results of investigations on an epizootic foot pustule disease resulting in mass mortality of cultured abalone $H$. discus hannai hybrids (H. discus hannai from Shandong province x H. discus hannai from Fujian province), from Guangdong Province, China.

\section{Materials and methods}

Clinical signs of diseased abalones

Diseased abalones $H$. discus hannai $(\mathrm{n}=40$; $50 \pm 3 \mathrm{~mm}, 2.5$ years old) were collected from an abalone farm (seawater temperature $28.5^{\circ} \mathrm{C}$ ) in Guangdong Province, China in June 2014. The abalones were transported to the laboratory in about $3 \mathrm{~h}$. To keep the abalones alive during transport, they were placed in polystyrene foam boxes containing ice packs. Clinical signs of diseased abalones were recorded and lesions measured and sampled for analyses.

\section{Isolation and identification of bacteria}

Samples collected aseptically from the foot muscle (focusing on the pustules), visceral mass and haemolymph were respectively streaked on brain-heart infusion (BHI) agar and thiosulfate citrate bile salts sucrose (TCBS) agar plates. The plates were incubated at $28^{\circ} \mathrm{C}$ for $96 \mathrm{~h}$. Dominant colonies were purified using gradient dilution and streak plate technique. Pure isolates were then stored at $-80^{\circ} \mathrm{C}$ in normal sterile saline (NSS, $0.85 \%$ ) with $20 \%$ glycerol (Wang et al., 2013b).

The dominant bacterial isolate designated as BV2 was identified by phenotypic traits using API 32E system (BioMerieux, France) as per Wang et al. (2013b) as well as by electron microscopy. The $16 \mathrm{~S}$ rDNA gene of the isolate was amplified by PCR using the bacterial universal primers, 27f 5'-AGAGTTTGATCCTGGCTCAG-3' and 1492r 5'-GGTTACCTTGTTACGACTT- 3' (Polz and Cavanaugh 1998). The toxR gene was also amplified using the primers toxR-f 5'-GAAGCAGCACTCACCGAT-3' and toxR-r 5'-GGTGAAGACTCATCAGCA-3' (Conejero et al., 2003). DNA extraction, PCR amplification and sequencing were done as per Kumar et al. (2004) and Wang et al. (2013b). Similar sequences from the GenBank database were selected for alignment, using CLUSTALX software (Thompson et al., 1997). The resulting alignment was checked and corrected manually using BioEdit (Hall, 1999). The neighbour-joining method and the maximum parsimony (MP) method were used to create phylogenetic tree, in MEGA3.1 (Kumar et al., 2004), using Kimura two-parameter model and pairwise deletion for gaps. MP analyses were conducted with PAUP*4.0b10. Clade support for both analyses was assessed by bootstrapping with 1000 replicates.

\section{Sensitivity to antibacterial agents}

The strain BV2 was tested for susceptibility against a total of 13 different antibiotics by the Kirby-Bauer (K-B) diffusion method (Wang et al., 2013b).

\section{Pathogenicity of dominant bacterial isolate}

The bacteria was cultured on BHI agar for 18-24 h $\left(28^{\circ} \mathrm{C}\right)$ and suspended and diluted in NSS. The bacterial density in each suspension was estimated by serial dilution and plating on $\mathrm{BHI}$ agar plates in triplicates. After $24 \mathrm{~h}$ incubation, colonies on the plates were counted. Abalones $H$. discus hannai from quarantined stocks certified as disease-free were used to assess pathogenicity of the isolate. The abalones were acclimated for 3-4 days in 501 tanks filled with oxygenated and filtered seawater at $28^{\circ} \mathrm{C}$. During this period, the abalones were not fed. Following acclimation, 12 groups (five experimental groups and one control, each group had 2 replicates) were formed, each containing 30 abalones (average weight $=3.5 \pm 0.5 \mathrm{~g}$, average shell length $=3.5 \pm 0.5 \mathrm{~cm}$, in 12 tanks each filled with 501 seawater). The abalones in the experimental groups were exposed to seawater containing the bacterial suspensions at concentrations of $8.7 \times 10^{3}$, $8.7 \times 10^{4}, 8.7 \times 10^{5}, 8.7 \times 10^{6}$, and $8.7 \times 10^{7} \mathrm{CFU} \mathrm{ml} \mathrm{m}^{-1}$ for 16 days, with sterile seawater used for preparation of bacterial suspension. The control group animals were maintained in normal seawater. The abalones were maintained for 16 days (the conditions identical to the acclimation period), during which disease symptoms and mortality were monitored daily. Samples collected aseptically from the feet and viscera of infected abalones were used to inoculate TCBS plates and BHI agar plates, which were then incubated at $28^{\circ} \mathrm{C}$ for $96 \mathrm{~h}$.

\section{Histopathology}

Infected tissues from the diseased abalones and healthy ones were fixed in 10\% neutral buffered formalin, dehydrated in ascending series of alcohol, embedded in paraffin, sectioned at 4-5 $\mu \mathrm{m}$ and stained using hematoxylin and eosin (H\&E).

\section{Results and discussion}

Characteristics of diseased abalones and pathogenicity of the dominant bacteria

Naturally infected abalones (shell length $=50 \mathrm{~mm}$ ) exhibited foot pustules and died in large numbers, with a mortality rate of approximately $60 \%$ in the farm in Shenzhen. During the early stages of infection (after 5-7 days), the foot contracted and presented small white spots. As the disease progressed, the white spots enlarged and developed into pustules with maximum diameter of $2 \mathrm{~cm}$ each in 12 or 15 days. At this stage, the pustules tended 
to rupture, releasing white pus and leaving holes $2 \sim 5 \mathrm{~mm}$ deep (Fig. 1). The dominant bacterium isolated from the nidus (pustules) of diseased abalones on BHI agar plates was designated as strain BV2. Pathogenicity assays by immersion challenge in healthy abalones revealed that strain BV2 was highly virulent (Table 1, Fig. 2). (a)

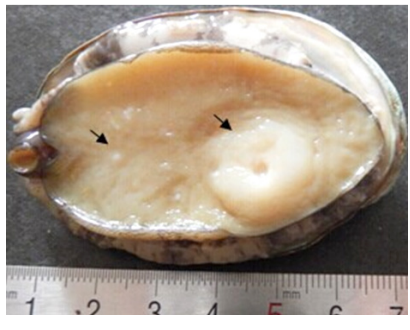

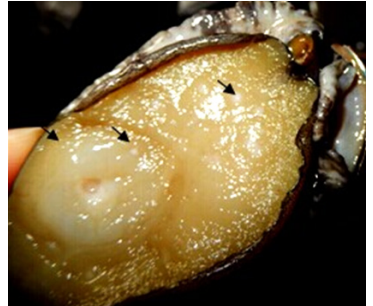

(b)
Fig. 1. Initial symptoms of pustules (arrows) scattered in the foot of naturally infected abalones infected abalones showed pustules in the foot (Fig. 3), which were similar to those in the naturally infected abalones. Similar bacterial strain as BV2 was re-isolated from the foot and entrails of moribund abalones. Histopathological examination showed that foot muscles and connective tissues degenerated and collapsed. Tissues in the round pustule were necrotic and disorganised (Fig. 4).

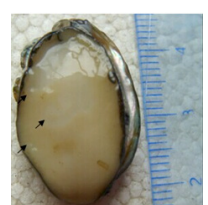

(a)

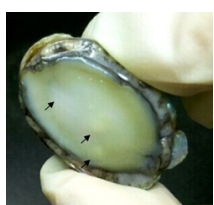

(b)

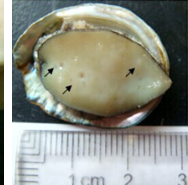

(c)

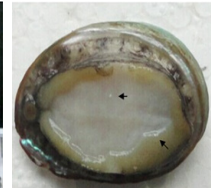

(d)
Fig. 3. Pustules (arrows) scattered in the foot of diseased abalone challenged by strain BV2

Table 1. Pathogenicity of strain BV2 to abalone H. discus hannai

\begin{tabular}{|c|c|c|c|}
\hline Group & $\begin{array}{l}\text { Final concentration of BV2 } \\
\text { in seawater }\left(\mathrm{CFU} \mathrm{m} \mathrm{m}^{-1}\right)\end{array}$ & $\begin{array}{l}\text { No. of abalones } \\
\text { in each group }\end{array}$ & $\begin{array}{l}\text { Average mortality rate (Immersion } \\
\text { challenge for } 16 \text { days) }\end{array}$ \\
\hline 1 & $8.7 \times 10^{3}$ & 30 & $60 \%$ \\
\hline 2 & $8.7 \times 10^{4}$ & 30 & $75 \%$ \\
\hline 3 & $8.7 \times 10^{5}$ & 30 & $85 \%$ \\
\hline 4 & $8.7 \times 10^{6}$ & 30 & $90 \%$ \\
\hline 5 & $8.7 \times 10^{7}$ & 30 & $100 \%$ \\
\hline Control & Normal seawater & 30 & 0 \\
\hline
\end{tabular}

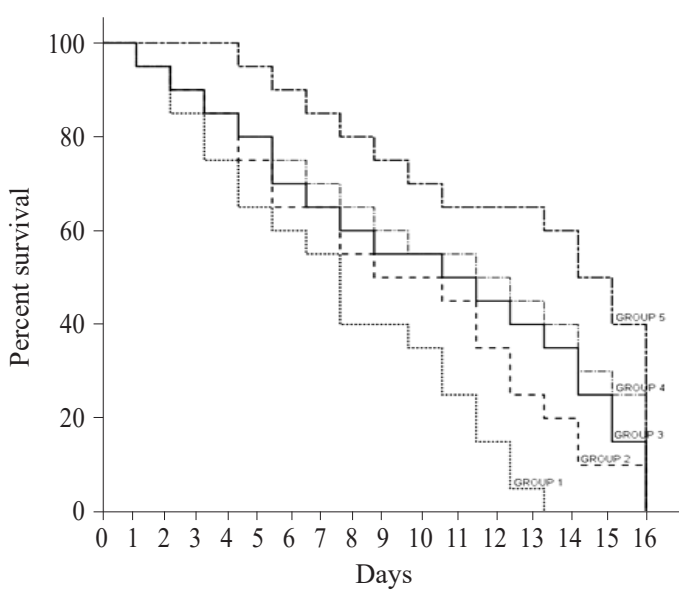

Fig. 2. Kaplan-Meier survival analysis of diseased abalone, immersion challenged with strain BV2: GROUP 1, $8.7 \times 10^{7} \mathrm{CFU} \mathrm{ml}{ }^{-1}$; GROUP 2, $8.7 \times 10^{6} \mathrm{CFU} \mathrm{ml}^{-1}$; GROUP 3, $8.7 \times 10^{5} \mathrm{CFU} \mathrm{ml}^{-1}$; GROUP $4,8.7 \times 10^{4} \mathrm{CFU}$ $\mathrm{ml}^{-1}$; GROUP $5,8.7 \times 10^{3} \mathrm{CFU} \mathrm{ml}^{-1}$. $(\mathrm{n}=30$ per group $)$

According to the improved Karber's method, the $\mathrm{LD}_{50}$ value of BV2 for immersion was $7.76 \times 10^{5} \mathrm{CFU} \mathrm{ml}^{-1}$ of seawater (temperature $=29.5^{\circ} \mathrm{C}, \mathrm{pH} 8.15$, 16 days after immersion exposure). Experimentally

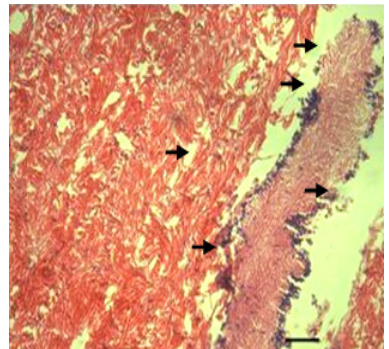

(a)

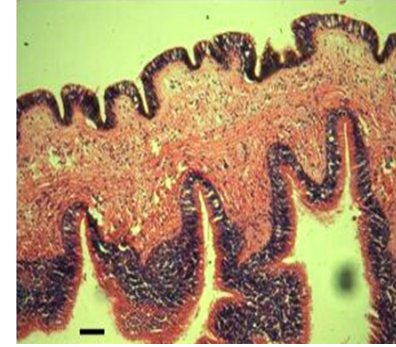

(b)
Fig. 4. Histological section of foot tissue from (a): Diseased abalone (scale bar $=50 \mu \mathrm{m}) ;(\mathrm{b})$ : Healthy abalone (scale bar $=90 \mu \mathrm{m}) \quad(\mathrm{H} \& \mathrm{E})$. Arrows indicate necrotic and disorganised foot pustules

\section{Characterisation and identification of bacterial strain BV2}

The isolate BV2 was found to be a Gram-negative, rod-shaped, and curved organism with one long flagellum and many pili (Fig. 5a). This strain was sensitive to the Vibrio inhibitor $\mathrm{O} / 129\left(10\right.$ and $\left.150 \mu \mathrm{g} \mathrm{ml}^{-1}\right)$. The BV2 isolate also demonstrated obvious $\beta$-hemolysin activity (Fig. 5b). Colonies of BV2 on TCBS agar were golden yellow, orbicular and smooth. The average diameter of the colonies was 2-3 $\mathrm{mm}$ after being cultured for $24 \mathrm{~h}$ (Fig. 5c). 


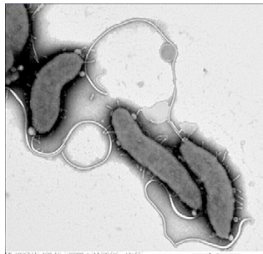

(a)

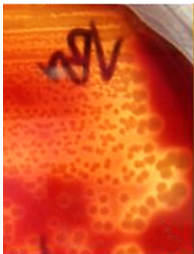

(b)

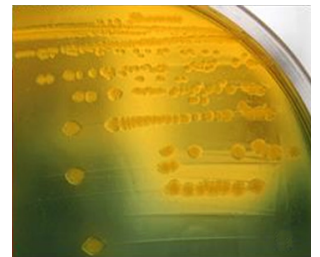

(c)
Fig. 5. Morphology of strain BV2. a: Electron micrograph of BV2 after negative staining; b: strong $\beta$-hemolysis by BV2 on blood agar; c: BV2 cultured on TCBS plate

Strain BV2 presented a relatively narrow salinity tolerance range and did not grow in 0 or $10 \% \mathrm{NaCl}$ but grew in 1, 2, 6 and 8\% (WPV) NaCl. Strain BV2 was identified as $V$. harveyi using the API 32E kit (\%id: 99.9, T: 0.51) which presented similar phenotypic traits as that of type strain $V$. harveyi ATCC14126 (Table 2). The strong ß-hemolysin (an important virulence factor) activity of $\mathrm{BV} 2$, indicates its virulence and all the infected abalones were kraurotic compared with the controls.

The edited and assembled 16S rDNA nucleotide sequences of the isolate BV2 resulted in a full-length sequence of $1420 \mathrm{bp}$. BLAST search of the GenBank database revealed that the gene sequence showed high similarity to members of $V$. harveyi ( $99 \%$ similarity, Fig. 6). Based on the similarity in more than 28 biochemical indices (employing API 32E system), with the type strain $V$. harveyi ATCC14126; and based on 16S rDNA sequence analysis, the strain BV2 was identified as $V$. harveyi.
Various diseases commonly caused by bacterial pathogens belonging to the genus Vibrio (Liu et al., 2003; Cai et al., 2007; Travers et al., 2008; Haldara et al., 2010; Wang et al., 2013a) have threatened the sustainable development of the abalone industry. Vibrios

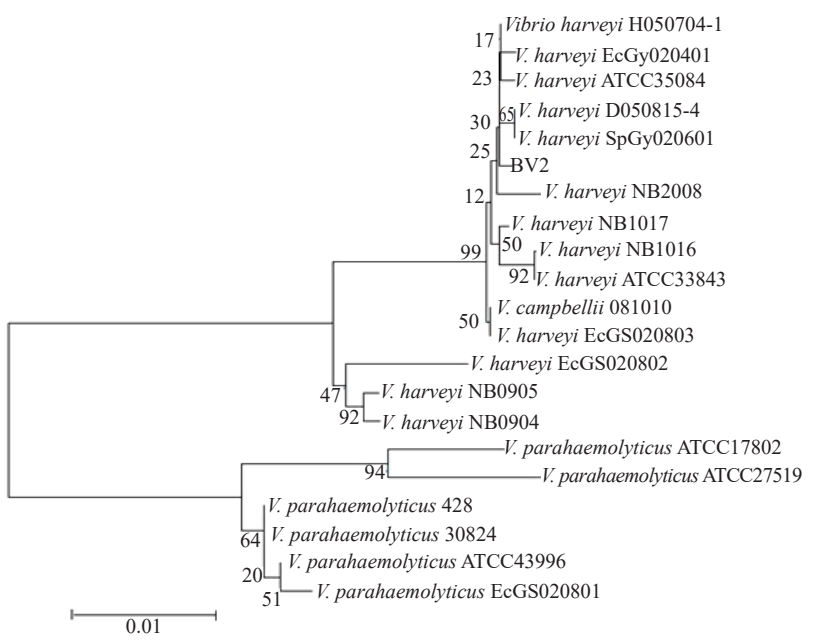

Fig. 6. Phylogenetic tree based on $16 \mathrm{~S}$ rDNA gene sequence of BV2

belonging to the harveyi clade comprises important pathogens of numerous marine animals. $V$. harveyi has been widely recognised as a common pathogen of many commercially cultured fish and shellfish species worldwide, including the Asian seabass Lates calcarifer (Tendencia, 2002; Ransangan et al., 2012), sea horse Hippocampus kuda (Tendencia, 2004), sea bream Sparus aurata

Table 2. Important phenotypic traits of BV2 in comparison with reference strain, $V$. harveyi ATCC14126

\begin{tabular}{|c|c|c|c|c|c|}
\hline Biochemical tests & BV2 & $\begin{array}{l}V . \text { harveyi } \\
\text { ATCC14126 }\end{array}$ & Biochemical tests & BV2 & $\begin{array}{l}\text { V. harveyi } \\
\text { ATCC14126 }\end{array}$ \\
\hline D-glucose & + & + & TDA & - & + \\
\hline Saccharose & + & + & Catalase & - & - \\
\hline Xylose & - & - & Urease & + & + \\
\hline Lactose & - & - & Gelatinase & + & + \\
\hline Raffinose & - & - & Arginine dihydrolase & + & + \\
\hline L-arabinose & - & - & Ornithine decarboxylase & - & - \\
\hline D-arabite & - & - & Lysine decarboxylase & - & - \\
\hline L-rhamnose & - & - & L-asparagic acid arylamine & - & - \\
\hline$\alpha$-maltobiose & - & - & $\alpha$-galactosidase & - & - \\
\hline D-maltobiose & + & + & $\beta$-galactosidase & - & - \\
\hline D-cellobiose & + & + & $\beta$-glucosidase & + & + \\
\hline D-mycose & + & + & $\beta$-glucuronidase & + & + \\
\hline Antiquity-sugar & - & - & $\mathrm{V}-\mathrm{P}$ & - & - \\
\hline D-mannite & - & - & Indole & - & - \\
\hline Inose & + & + & $\mathrm{H}_{2} \mathrm{~S}$ & + & + \\
\hline Adonitol & - & - & Nitrate & - & - \\
\hline Sorbierite & + & + & Citrate & - & - \\
\hline Salicin & - & - & Malonate & - & - \\
\hline Oxidase & + & + & D-Galactose acid & - & - \\
\hline ONPG & + & + & $\beta$-acet-glucosamine & - & - \\
\hline
\end{tabular}


(Haldar et al., 2010), red drum Sciaenops ocellatus, cobia Rachycentron canadum (Liu et al., 2001; 2004), shrimp Penaeus chinensis (Vandenberghe et al., 1998), Arabian surgeon fish Acanthurus sohal (Mahmoud and Manal, 2013) and abalones $H$. tuberculata and $H$. diversicolor (Nicolas et al., 2002; Huang et al., 2005; Sawabe et al., 2007; Jiang et al., 2010; Schikorski et al., 2013). However, only less than $5 \%$ of $V$. harveyi strains are believed to be capable of initiating disease in humans (Kanga et al., 2014).

Foot pustule disease is a serious concern for abalone aquaculture, which results in mass mortalities of abalones in China, especially during summer. The present study demonstrated that $V$. harveyi was a single pathogen that caused foot pustule disease in $H$. discus hannai with $\mathrm{LD}_{50}$ value of $7.76 \times 10^{5} \mathrm{CFU} \mathrm{m}{ }^{-1}$ in immersion challenge. In recent years, though $V$. harveyi has frequently been reported as a causative bacterium for disease in mollusks, including abalones and oysters, affirming its pathogenicity is difficult because the symptoms are not visible (Nicolas et al., 2002; Wang et al., 2010; Wang et al., 2012; Wang et al., 2013a; Cardinaud et al., 2015; Sweet and Bateman, 2015). The LD50 values of many $V$. harveyi strains were reported to range from $10^{4}$ to $10^{6} \mathrm{CFU} \mathrm{ml}{ }^{-1}$ (Sawabe et al., 2007). In this study, symptoms caused by BV2 was different from that caused by other pathogenic $V$. harveyi strains (Sawabe et al., 2007; Travers et al., 2009; Qiang, 2013).

\section{Sensitivity to antibiotics}

The pathogenic bacterium BV2 was found resistant to kanamycin and clindamycin while it was sensitive to all other antibiotics tested (Table 3 ), suggesting the possibility of employing chemotherapeutic agents to control this pathogen. However, selective pressure when using antibiotics may increase or even induce antibiotic resistance among bacteria (Alderman et al., 1998; Smith, 2008; Heuer et al., 2009; Wang et al., 2014; Wang et al., 2015) and hence use of antibiotics

Table 3. Antibiotic susceptibility of BV2 to 13 different antibiotics

\begin{tabular}{lll}
\hline Antibiotic & $\begin{array}{l}\text { Antibiotic concentration } \\
\text { per disc }\end{array}$ & Susceptibility \\
\hline Penicillin & $10 \mathrm{u}$ & $\mathrm{I}$ \\
Sulfamethoxazole/ & $23.75 / 1.25 \mu \mathrm{g}$ & $\mathrm{S}$ \\
Trimethoprium & & \\
Erythromycin & $15 \mu \mathrm{g}$ & $\mathrm{I}$ \\
Kanamycin & $30 \mu \mathrm{g}$ & $\mathrm{R}$ \\
Gentamicin & $10 \mu \mathrm{g}$ & $\mathrm{I}$ \\
Florfenicol & $30 \mu \mathrm{g}$ & $\mathrm{S}$ \\
Tetracycline & $30 \mu \mathrm{g}$ & $\mathrm{I}$ \\
Neomycin & $30 \mu \mathrm{g}$ & $\mathrm{I}$ \\
Streptomycin & $10 \mu \mathrm{g}$ & $\mathrm{S}$ \\
Clindamycin & $20 \mu \mathrm{g}$ & $\mathrm{R}$ \\
Doxycycline & $30 \mu \mathrm{g}$ & $\mathrm{S}$ \\
Azithromycin & $15 \mu \mathrm{g}$ & $\mathrm{S}$ \\
Cefixime & $30 \mu \mathrm{g}$ & $\mathrm{S}$ \\
\hline
\end{tabular}

R: Resistant, I: Intermediate, S: Sensitive in aquaculture facilities should be controlled strictly. Other control methods such as the use of probiotics and prebiotics (Ravi et al., 2007), UV treatment of seawater, disinfection and frequent cleaning of facilities and also lowering stocking density to avoid stress to abalones can be tried preemptively before diseases occur.

\section{Acknowledgements}

This study was financially supported by grants from the Ear-marked Fund for Modern Agrotechnology Research System (CARS-48), Special Funds for Fishery Disease Prevention and Control in Guangdong Province (2014-585) and Special Scientific Research Funds for Central Non-profit Institutes, South China Sea Fisheries Research Institute, Chinese Academy of Fishery Sciences (2014TS29, 2016TS09).

\section{References}

Alderman, D. J. and Hastings, T. S. 1998. Antibiotic use in aquaculture: development of antibiotic resistance-potential for consumer health risks. Food Sci. Technol. Int., 33: 139-155.

Allsopp, M., Cruz, F. L. L., Flores-Aguilar, R. and Watts, E. 2012. Abalone culture: In: Fotedar, R. K., Phillips, B. F. (Eds.), Recent advances and new species in aquaculture, Wiley-Blackwell, United Kingdom, 231 pp.

Ananda Raja, R., Panigrahi, A., De, D. and Sujeet Kumar 2017a. Investigation on white spot disease outbreak in Penaeus monodon (Fabricius, 1798) in association with Vibrio mimicus infection in the Sunderbans, West Bengal, India. Indian J. Fish., 64: 56-60.

Ananda Raja, R., Sridhar, R., Balachandran, C., Palanisammi, A., Ramesh, S. and Nagarajan, K. 2017b. Pathogenicity profile of Vibrio parahaemolyticus in farmed Pacific white shrimp, Penaeus vannamei. Fish Shellfish Immunol., 67: 368-381.

Cai, J., Li, J., Thompson, K. D., Li, C. and Han, H. 2007. Isolation and characterisation of pathogenic Vibrio parahaemolyticus from diseased post-larvae of abalone Haliotis diversicolor supertexta. J. Basic Microbiol., 47: 84-86.

Cardinaud, M., Dheilly, N. M., Huchette, S., Moraga and Paillard, C. 2015. The early stages of the immune response of the European abalone Haliotis tuberculata to a Vibrio harveyi infection. Dev. Comp. Immunol., 51: 287-297.

Cardinaud, M. C., Offret, S., Huchette, D. Moraga and Paillard, C. 2014. The impacts of handling and air exposure on immune parameters gene expression and susceptibility to vibriosis of European abalone Haliotis tuberculata. Fish Shellfish Immunol., 36: 1-8.

Chen, A. P., Jiang, Y. L., Qian, D., Chen, C. F., Li, A. X., Huang, J. and Yang, B. 2011. Pustule disease. China Fisheries, (12): 46-47.

Conejero, M. J. and Hedreyda, C. T. 2003. Isolation of partial toxR gene of Vibrio harveyi and design of toxR-targeted 
PCR primers for species detection. J. Appl. Microbiol., 95(3): 602-611.

Flores-Aguilar, R. A., Gutierrez, A., Ellwanger, A. and SearcyBernal, R. 2007. Development and current status of abalone aquaculture in Chile. J. Shellfish Res., 26: 705-711.

Goodsell, P. J., Underwood, A. J., Chapman, M. G. and Heasman, M. P. 2006. Seeding small numbers of cultured black-lip abalone (Haliotis rubra Leach) to match natural densities of wild populations. Mar. Environ. Res., 57: 747-756.

Gorski, J. and Nugegoda, D. 2006. Sublethal toxicity of trace metals to larvae of the blacklip abalone Haliotis rubra. Environ. Toxicol. Chem., 25: 1360-1367.

Gauger, E. J. and Gomez-Chiarri, M. 2002. 16S ribosomal DNA sequencing confirms the synonymy of Vibrio harveyi and V. carchariae. Dis. Aquat. Organ., 5239-5246.

Haldara, S., Maharajan, A., Chatterjee, S., Hunter, S. A., Chowdhury, N., Hinenoya, A., Asakuraa, M. and Yamasaki, S. 2010. Identification of Vibrio harveyi as a causative bacterium for a tail rot disease of sea bream Sparus aurata from research hatchery in Malta. Microbiol. Res., 165(8): 639-648.

Hall, T. A. 1999. Bioedit: a user-friendly biological sequence alignment editor and analysis program for Windows 95/98/ NT. Nucleic Acids Symposium Series, 41: 95-98.

Heuer, O. E., Kruse, H., Grave, K., Collignon, P., Karunasagar, I. and Angulo, F. J. 2009. Human health consequences of use of antimicrobial agents in aquaculture. Clin. Infec. Dis., 15: 1248-1253.

Huang, W. H. 2005. Analysis of impe tigo occurred to small abalone Haliotis diversicolor supertexta cultured in Fujian and its sensibility to drugs. J. Oceanogr. Taiwan Strait., 24(4): 526-532.

Jiang, J. Z., Zhang, W., Wang, J. Y., Wang, R. X. and Liu, G. F. 2010. Construction of whole body normalized cDNA library of Haliotis diversicolor Reeve challenged by Vibrio harveyi. South China Fish. Sci., 6(5): 37-42.

Jo, Y. J., Jung, K. H., Lee, M. Y., Choi, M. J., Min, S. G. and Hong, G. P. 2014. Effect of high-pressure short-time processing on the physicochemical properties of abalone (Haliotis discus hannai) during refrigerated storage. Inno. Food Sci. Emerg. Technol., 23: 33-38.

Kang, C. H., Kim, Y. G., Oh, S. G., Mok, J. S., Cho, M. H. and So, J. S. 2014. Antibiotic resistance of Vibrio harveyi isolated from seawater in Korea. Mar. Pollut. Bull., 86(1-2): 261-265

Kumar, S. and Tamura, K. and Nei, M. 2004. MEGA3: integrated software for molecular evolutionary genetics analysis and sequence alignment. Brief. Bioinform., 5: 150-163.

Li, T. W., Zhang, J., Ding, M. J., Wang, S. J., Shi, P., Xiang, J. H. and Liu, R.Y.1997. Histology and ultrastructure of pustule disease in abalone Haliotis discus hannai (mollusca: gastropoda). Acta. Zool. Sinica, 43(3): 238-242.
Liu, P. C., Chen, Y. C. and Lee, K. K. 2003. Pathogenicity of Vibrio alginolyticus isolated from diseased small abalone Haliotis diversicolor supertexta. Microbios, 104: 71-77.

Liu, P. C., Chuang, W. H. and Lee, K. K. 2001. Infectious gastroenteritis caused by Vibrio harveyi ( $V$. carchariae) in cultured red drum Sciaenops ocellatus. J. Appl. Ichthyol., 19(1): 59-61.

Liu, P. C., Lin, J. Y., Chuang, W. H. and Lee, K. K. 2004 Isolation and characterisation of pathogenic Vibrio harveyi (V. carchariae) from the farmed marine cobia fish Rachycentron canadum L with gastroenteritis syndrome. World J. Microbiol. Biotechnol., 20: 495-499.

Mahmoud, H. and Manal, E. 2013. Vibrio harveyi infection in Arabian Surgeon fish (Acanthurus sohal) of Red Sea at Hurghada Egypt. Egyptian J. Aquat. Res., 39: 199-203.

McBride, S. C. 1998. Current status of abalone aquaculture in the Californias. J. Shellfish Res., 17: 593-600.

Nicolas, J. L., Basuyaux, O., Mazurie, J. and Thebault, A. 2002. Vibrio carchariae a pathogen of the abalone Haliotis tuberculata. Dis. Aquat. Organ., 50: 35-43.

Qiang, Q. R., Shi, L. Y., Ke, C. H. and Zhao, J. 2013. Identification and characterisation of Vibrio harveyi associated with diseased abalone Haliotis diversicolor. Dis. Aquat. Org., 103(2): 133-139.

Ransangan, J., Lal, T. M. and Al-Harbi, A. H. 2012. Characterisation and experimental infection of Vibrio harveyi isolated from diseased Asian seabass (Lates calcarifer). Malay. J. Microbiol., 8(2): 104-115.

Ravi, A. V., Musthafa, K. S., Jegathammbal, G., Kathiresan, K. and Pandian, S. K. 2007. Screening and evaluation of probiotics as a biocontrol agent against pathogenic vibrios in marine aquaculture. Lett. Appl. Microbiol., 45: 219-223.

Sawabe, T., Fukui, S. Y., Yoshie, K., Nishihara, Y. and Miura, H. 2007. Mass mortalities of Japanese abalone Haliotis discus hannai caused by Vibrio harveyi infection. Microbes Environ., 22: 300-308.

Schikorski, D., Renault, T., Paillard, C., Bidault-Toffin, A., Tourbiez, D. and Saulnier, D. 2013. Development of TaqMan real-time PCR assays for monitoring Vibrio harveyi infection and a plasmid harbored by virulent strains in European abalone Haliotis tuberculata aquaculture. Aquaculture, 392-395: 106-112.

Shepherd, S. A. 1973. Studies on southern Australian abalone (genus Haliotis): Ecology of five sympatric species. Australian J. Mar. Freshw. Res., 24: 217-257.

Smith, P. 2008. Antimicrobial resistance in aquaculture. Rev. Sci. Technol., 27: 243-264.

Sweet, M. J. and Bateman, K. S. 2015. Diseases in marine invertebrates associated with mariculture and commercial fisheries. J. Sea Res., 104: 16-32. 
Tendencia, E. A. 2002. Vibrio harveyi isolated from cagecultured seabass Lates calcarifer Bloch in the Philippines. Aquac. Res., 33(6): 455-458.

Tendencia, E. A. 2004. The first report of Vibrio harveyi infection in the sea horse Hippocampus kuda Bleekers 1852 in the Philippines. Aquac. Res., 35(13): 1292-1294.

Thompson, J. D., Gibson, T. J., Plewniak, F., Jeanmougin, F. and Higgins, D. G. 1997. The Clustal X windows interface: flexible strategies for multiple sequence alignment aided by quality analysis tools. Nucl. Acids Res., 24: 4876-4882.

Travers, M. A., Basuyaux, O., Le Goic, N., Huchette, S., Nicolas, J. L. and Koken, M. 2009. Influence of temperature and spawning effort on Haliotis tuberculata mortalities caused by Vibrio harveyi: an example of emerging vibriosis linked to global warming. Global Change Biol., 151: 365-1376.

Travers, M. A., Le, G. N., Huchette, S., Koken, M. and Paillard, C. 2008. Summer immune depression associated with increased susceptibility of the European abalone Haliotis tuberculata to Vibrio harveyi infection. Fish Shellfish Immunol., 25: 800-808.

Travers, M. A., Meistertzheim, A. L., Cardinaud, M., Friedman, C. S., Huchette, S. and Morag, D. 2010. Gene expression patterns of abalone Haliotis tuberculata during successive infections by the pathogen Vibrio harveyi. J. Invert. Pathol., 105(3): 289-297.

Wang, K. J., Ren, H. L., Xu, D. D., Cai, L. and Yang, M. 2008. Identification of the up-regulated expression genes in hemocytes of variously colored abalone (Haliotis diversicolor Reeve 1846) challenged with bacteria. Dev. Comp. Immunol., 32: 1326-1347.

Wang, R. X., Geng, Y. J., Feng, J. and Wang, J. Y. 2012. Identification and analysis of resistant plasmid of pathogenic bacteria Vibrio harveyi isolated from Haliotis diversicolor. South China Fish. Sci., 8(2): 1-6.

Wang, R. X., Feng, J., Su, Y. L., Ye, L. T. and Wang, J. Y. 2013b. Studies on the isolation of Photobacterium damselae sub sp. piscicida from diseased golden pompano (Trachinotus ovatus Linnaeus) and antibacterial agents sensitivity. Vet. Microbiol., 163: 957-963.

Wang, J. Y., Sun, X. X., Wang, R. X. and Su, Y. L. 2010. Isolation identification and phylogenetic analysis of pathogen from Haliotis diversicolor Reeve with withering syndrome. South China Fish. Sci., 6(5): 22-26.

Wang, R. X., Wang, A. L. and Wang, J. Y. 2014. Antibiotic resistance monitoring in heterotrophic bacteria from anthropogenic-polluted seawater and the intestines of oyster Crassostrea hongkongensis. Ecotox. Environ. Safe., 10: $927-931$

Wang, R. X., Wang, J. Y., Sun, Y. C., Yang, B. L. and Wang, A. L. 2015. Antibiotic resistance monitoring in Vibrio spp. isolated from rearing environment and intestines of abalone Haliotis diversicolor. Mar. Pollut. Bull., 101: 701-706.

Wang, R. X., Xu, L.W., Feng, J. and Wang, J. Y. 2006. Advances in studies on diseases caused by microoranisms of abalone. Chin. J. Oceanol. Limnol., 2: 117-124.

Wang, J. Y., Wang, R. X., Su, Y. L., Wu, K. C., Guo, Z. X. and Jiang, J. Z. 2013a. Pathogen and pathology of "acute death syndrome" of Babylonia areolata. South China Fish. Sci., 9(5): 93-99.

Vandenberghe, J., Li, Y., Verdonck, L., Li, J., Sorgeloos, P. and Xu, H. S.1998. Vibrios associated with Penaeus chinensis larvae in Chinese shrimp hatcheries. Aquaculture, 169: 121-132. 